\title{
Warburton, N. (2012). Vprašanje umetnosti [The Art Question] $]^{1}$. Afterword study by Marjan Šimenc. Ljubljana: Sophia. 158 p., ISBN 978-961-6768-48-1.
}

Reviewed by BLAž ZABEL ${ }^{2}$

Nigel Warburton is a philosopher, best known for his work in the popularisation of philosophy across the globe. The podcast series he made with David Edmonds, Philosophy Bites, publishing interviews with some of the most noted philosophers of our time, was a monumental success - as were many of his other written works, especially Philosophy: The Basics, Philosophy: The Classics and Thinking from $A$ to $Z$. Besides the extensive work he has done for the promotion of philosophy, Nigel Warburton is also an influential author for art theory and history, specialising in photography and architecture; he has written about Ernö Goldfinger in his book Ernö Goldfinger: The Life of An Architect and edited a book about the photographer Bill Brandt. The Art Question is his attempt to summarise the analytical tradition of modern art theory. At the same time, however, the author builds, with different comments and critical remarks, his own standpoint. His own contribution to art theory is clearly explicated in the last chapter.

In his work, Nigel Warburton is interested in the question: 'What is art?' The question is, he adds, equally important for the aesthetics of the 2oth century as well as for artists and art itself. Already in the introduction, he contradictorily remarks that the question of art is more in the domain of philosophy than in the domain of arts. He even hints that the sole question is worth tackling simply because it is a complicated one. This position can be followed throughout his book: while the author investigates different aesthetic theories and even interprets different art works with their help, he constantly provides counter-examples to prove them wrong, stating that art is not something theory can fully embrace and define.

The Art Question is divided into five chapters, each devoted to a certain theoretical aspect in the history of aesthetics. The first chapter is devoted to the formalist theory of Clive Bell, which argues that the form of the picture is essential for its aesthetic value and experience. In the second chapter, Warburton analyses the expressive theory of art as introduced by R. G. Collingwood. The third chapter examines the idea that the concept of art bears so-called family

1 Translation of the original Warburton, N. (2003). The Art Question. London: Routledge.

2 Faculty of Education, University of Ljubljana, Slovenia 
resemblance, an idea introduced by Ludwig Wittgenstein. The idea of family resemblance signifies that there is no actual rule to describe all the forms of art and all the artistic objects, but each of them must have at least one resemblance to at least one other. In the fourth chapter, the author analyses the well-known institutional theory of art, which was introduced by philosopher George Dickie, who stated, that 'a work of art in the classificatory sense is 1) an artefact 2) upon which some person or persons acting on behalf of a certain social institution (the art world) has conferred the status of candidate for appreciation'. This eventually means that everything can be presented as art, as long as the 'the art world' accepts it as such.

The most intriguing part of the book is by all means the last chapter, which contains Warburton's own contribution to the theoretical discourse about art. He would suggest that it is not possible to define art, since all works of art do not have even one collective characteristic. However, the definition of art is still useful for three reasons: it helps us discuss borderline examples, it helps us understand why something was declared art in the past, and finally, it shows which objects will satisfy us if we pay particular attention to this particular object. The author tries to demonstrate his hypothesis with comparison of two photographers, Cindy Sherman and Stuart Franklin. While Sherman has been accepted into art canon as an artist, Franklin is regarded more as an esteemed journalist photographer. Their photographs are labelled differently, although there is no definable difference between them. What Nigel Warburton suggests in The Art Question is that we ought to stop searching for an absolute definition of art but rather try to discuss particular works of art. We should be interested in real artistic work rather than in the general idea of art that is detached from artistic objects.

This position, however, is in itself contradictory. While Warburton argues that the absolute definition of art is not possible, he proposes just such a definition. If he says that 'no definition is possible', his position is in the same way total and all-embracing as the absolute definition of art. He assumes the same logic as all of the theoreticians he tries to oppose. The assertion 'there is no possible definition of art' is in no way different from any other definition, as it is in the same way absolute and should apply to all possible examples. This fallacy can be certified by analysing the author's methodological approach. Following Jakobson's communication model, we can understand different approaches to art in the following schematic: author-work-context-audience. For instance, to oppose Dickie's institutional theory, Warburton provides the example of outsider art, which is produced outside the art world. This argument clearly focuses on the author's production and intention, and on the aesthetic 
characteristics of the work itself, while forgetting the reception of the artwork. Outsider art might truly be produced and exist outside all the artistic institutions, but its reception is dependent on them. What Nigel Warburton is doing is to think about the art as it is on itself; in other words, he talks about the general idea of art (which is in his opinion impossible to define). In all of his arguments, he is stating that art is just art, without production, reception, context etc. In this way, he assumes the art as an idea while trying to argue against it. Or, as said above, he is opposing the theoretical definition of art while stating his own theoretical definition of art.

Moreover, the equalisation between the theory and the definition Warburton (unconsciously?) applies bears heavy consequences. Arguing that the main purpose of theory, in this case, art theory, is to propose a definition, is a grave diminution of theory itself. Accepting the position that theory is not necessary for understanding of art might result in a 'passive approach' to art (a term used by Terry Eagleton for literature), since theory is always a part of understanding of artistic objects. It may not be the only way of its understanding, but it plays and has always played a vital role. Arguing that theory is talking only about the definition of art or the general idea of art is simply not tenable. It can be plausible only if we falsely assume that the sole purpose of art theory is to find some absolute and general rule about art. But theory is, as Nigel Warburton demonstrates throughout his discussion about different aesthetic theories, much more than that. It is a way of thinking about art, a way of understanding and comprehending different artistic objects, a way in which we interpret them. Thus, Warburton's call to focus on particular works of art should not exclude art theory but rather include it.

Nevertheless, The Art Question brings us, in a highly understandable and readable form, a survey of some of the most notable aesthetic theories of our century, which are constantly questioned and challenged by critical commentaries. Furthermore, every theory and their problematic aspects are well demonstrated with different art works from the same period. However, Warburton's own theoretical contribution, while equally readable and comprehensible, is much less plausible. First, the author is unclear about what art theory actually is, as it sometimes seems it is nothing more than defining what art is. Second, his argument that it is not possible to define art is made from the same absolute position he is trying to oppose. He urges us to start discussing particular works of art, but at the same time assumes the opposite, the absolute and general idea of art. 